\title{
THE SCIENTIFIC PARADIGM OF ISLAMIC EDUCATION MANAGEMENT: PHENOMENOLOGY PERSPECTIVE
}

\author{
Philip Buckley \\ Department of Philosophy McGill University \\ Leacock Building, Room 414, 855 Sherbrooke Street West \\ Montreal, Quebec, H3A 2T7, Canada Tel. 514-398-6060 \\ Email: philip.buckley@mcgill.ca
}

\section{Irawan}

State Islamic University (UIN) Sunan Gunung Djati Bandung, Indonesia Jl. A. H. Nasution No. 105 Bandung, West Java

Email: Iraonetea@yahoo.com

\begin{abstract}
This paper intends to explore the possibility that phenomenology can be used as one of the foundations of scientific epistemology of Islamic education management. Scientific management of Islamic education would not be sufficient if only positivistic approached scientifically. Behaviors that contain messages of moral, theological and ideological embraced by managers, implementers and users of Islamic educational institutions are very complicated. To be able to describe these phenomena with a reasonable and until the deeply meaning (eidos), so phenomenological approach is needed. This approach can be used as a basis in developing others the science of Islamic education management. The science of Islamic education management can have a number of scientific fields (The science of diniyyah, madrassas, Islamic schools, and Islamic higher education management) and gave birth to a number of expertise (administrative staff, headmaster and superintendent at the madrasah level).
\end{abstract}

Keywords: Paradigm, Phenomenology, Islamic Education Management

\begin{abstract}
ABSTRAK
Tulisan ini bermaksud mengeksplorasi sejumlah kemungkinan bahwa fenomenologi dapat dijadikan sebagai salah satu landasan epistemologi keilmuan manajemen pendidikan Islam. Keilmuan manajemen pendidikan Islam tidak akan memadai jika hanya didekati secara ilmiah positivistik. Perilaku-perilaku yang mengandung pesan-pesan moral, teologis dan ideologis yang dianut oleh para pengelola, pelaksana dan pengguna lembaga pendidikan Islam sangat kompleks dan rumit. Agar dapat menggambarkan fenomena-fenomena tersebut dengan wajar dan sampai kepada makna yang tterdalam (eidos) maka diperlukan pendekatan fenomenologis. Pendekatan ini dapat dijadikan sebagai landasan dalam mengembangkan ilmu
\end{abstract}


manajemen pendidikan Islam. Ilmu manajemen pendidikan Islam bisa memiliki sejumlah bidang keilmuan (ilmu manajemen madrasah, pesantren, diniyyah dan perguruan tinggi Islam) dan melabirkan sejumlah keablian (tenaga administrasi di madrasah, kepala madrasah dan pengawas madrasab).

Kata Kunci : Paradigma, Fenomenologi, Manajemen Pendidikan Islam

\section{INTRODUCTION}

Around the year of 2009s, a study of Islamic Education Management often done in almost all Islamic Religious Higher Education Institution (PTKI) in Indonesia. This phenomenon is gaining momentum after a number of State of Islamic Institute (IAIN) (Jakarta, Yogyakarta, Malang and Bandung) in the time frame of 2004-2006s, successfully transformed institutional and management become State of Islamic University (UIN). In the same year, Majors of Department of Islamic Education (Kependidikan Islam) was renamed the Department/Studies Program of Islamic Management (Manajemen Pendidikan Islam) (PMA No. 39 of 2009). Since then, a number of Islamic Universities (UIN, IAIN, STAIN and other STAI) began to open MPI Programs and rename KI Study Programs be MPI program.

In 2012s, the Faculty of Tarbiyah and Teacher Training of UIN Sunan Gunung Jati Bandung changed the KI program into the Department of MPI and got accreditation A in the 2013. In this year, the Post Graduate Program of UIN Sunan Gunung Jati Bandung was opened for Magister Program of Islamic Education Management. Until the year 2013, there are approximately 40 MPI graduate programs throughout Indonesia scattered UIN, IAIN, STAIN, and some Islamic Higher Education Partikelir Indonesia. In that year, they agreed to make an MPI graduate program Communication Forum in Indonesia. On May 24, 2014, they declared the establishment of the Association of Islamic Education Management Scholars (ASMAPI) Indonesia in Bandung. This association is independent and focused on scientific development and Islamic education management in practice. The first Conference of ASMAPI-Indonesia take place at Bandung on 25-27 November 2015. In 2015 changed be ASPIMAPI-Indonesia (The Indonesian Association of Islamic Education Management Scholars, Professions, and Institutions).

This paper intends to respond to the rapid development of Islamic education management study to formulate a foundation of epistemological scientific MPI, so that MPI had a basic science that clearly so that its existence as a science recognized as part of science education Islam (Islamic Education/Tarbiyah science) and a branch of Islamic Sciences (Studies). Epistemological approaches that are used to build the science of Islamic 
education management in this paper is phenomenology. In phenomenology, the whole event, events, actions and activities of management of education in Islamic educational institutions into ground of data construct theories of Islamic education management. The basic of epistemic principles are then formulated a design of MPI-based research methodology of phenomenology, the paradigm of natural and typicaly the scientific Indonesian MPI.

\section{DISCUSSION}

\section{The Spirituality of Management}

So many management change projects that integrate spirituality in their organizational development. This spiritualization of corporations is not a return to Weber's traditional mode of legitimating, but rather an integrated part of a modern project of aesthetization and spiritualization of the discourse of management. There are the focus on values in the corporations (i.e., to make them be conscious of values and to refer to the vision and missions of the corporation) is made easy through the creation of collective spiritual values expressed through New Age mythology (Rendtorff in Koslowski, 2010. p. 19).

Spiritualized management allows for personal development and individual self-realization in corporations, rather than reducing human beings to work machines; employees are taken seriously as complex beings. From the New Age perspective of Eastern mythology, the justification for business ethics and corporate social responsibility are based in ideas of the soul. Each individual should demonstrate the capacity to take responsibility for him or herself, for their community, and for society. The anthropologist Karen Lisa Salmon argues that this position can easily be integrated into a neoliberal conception of the economy, because it is based on individualism. We see that it starts with the feelinas and emotions of individuals and their spiritual understandings of themselves and their responsibility. Moreover, it is a dogma of the New Age movement in management that personal success is based on the holistic integration of spiritual, private, and professional life. This is why management has become "whole-life management". Spiritual management is based on a kind of the law of Karma, where the journey into the self contributes to the enrichment of organizational life. Whole-life management helps to integrate the individual in the cosmos, to bring about a closer relationship between the self and the world. The idea is that whole-life management integrates personal desire and the sense for the community so that the journey into the self will in the end, be better for the common good (Rendtorff in Koslowski, 2010, p. 38).

An example of this kind of whole-life management can be found in the book Corporate Religion by the Danish marketing expert, Jesper Kunde. 
Kunde is a very good example of the New Age approach in his dissatisfaction with the secularization of business and with the demotivation of those working under increasing bureaucratization. His work can be conceived as an effort to reckon with the dissolution of Protestant ethics in modern business. Kunde argues that clearly focused strategies, which are based on strong values, are conditions for corporate survival in a society of fragmenting values. Both employees and customers have to be bonded emotionally to the corporation, if the corporation is going to have a chance for survival and growth in a competitive world economy (Rendtorff in Koslowski, 2010, p. 38).

Kunde argues for a return to a religiously based corporation and a strategy of corporate religion that is not only based in rational and economic bottom-line values, but that also grounds strategy and management holistically in the qualitative and emotional values of the corporation. According to this conception, "religion" (conceived as common visions, ideals, and ideology) is necessary for creating a well-functioning modern corporation. In a number of case studies of corporations such as Microsoft, Coca Cola, Walt Disney and The Body Shop, Kunde shows how these corporations can be said to operate according to a concept of corporate or brand religion, where the corporation is organized around strong common values and where the consumer is strongly emotionally related to the products (Rendtorff in Koslowski, 2010, p. 39).

This idea of corporate religiosity can be considered as a response to the lack of spirituality in modern management strategies-from scientific to total quality management. It is also a reaction toward the growing fragmentation and dissolution of work life in times where the Protestant ethos has been weakened. Without corporate religion it is not possible to tie together a corporation, which encounters many secular and multicultural challenges, to its corporate identity and unified culture. In order to cope with the loss of meaning in modern society, Kunde presents strong and very well-formulated values and values-driven management as responses to the problems of leadership in corporations. The firm should work with immaterial values in values-driven management by formulating its vision and mission in order to ensure commitment and action from its employees. The conscious religious strategy of values-driven management is about belief, community, strong management, and commitment and engagement in work. The product of the firm should be branded as something very special so that it is not just some other thing to buy: It should be endorsed by consumers as something vital for their identities and existence (Rendtorff in Koslowski, 2010, p. 39).

A very classical example is the American motorbike corporation Harley Davidson, which can be characterized as a corporation with a strong brand 
that understands the necessity to cultivate immaterial corporate values should be viewed as a good thing. It shows that a company has a clear idea and that this brand has been communicated efficiently to the environments. Kunde's concept of corporate religion is not designed to be cynical or nihilistic, but a rather loose concept, in the sense that "religion" means to have values and believe them. I think that this concept of corporate religion is, however, still problematic because the metaphor changes the corporation info a kind of religious sect with all the implications of manipulation, domination, and ideology that such a characterization entails (Rendtorff in Koslowski, 2010, p. 40).

Even though they are not necessarily better than other motorbike products, a Harley Davidson motorcycle is considered as much more than a simple motorbike. It is rather a lifestyle signifier, a form of identification, and possessing one is even viewed by many as the key to freedom and a part of achieving the American dream. At a time when the corporation was about to go bankrupt, Harley Davidson invented a new strategy whereby the firm focused on brand value, which, in this context, we might call the religious and emotional image of the corporation. They actively worked to create a community where customers and employees became emotionally linked to the firm. We might even say that they were encouraged to become disciples of the congregation of Harley Davidson (Rendtorff in Koslowski, 2010, p. 40).

Kunde draws our attention to the branding and strategy of the cosmetics company The Body Shop. The Body Shop operates as a political company, which has been able to combine the political and the religious content in the image of its products. Their brand is riot only about selling cosmetics but they are perceived as a knowledge-based company, which uses its product to encourage an environmental consciousness and lifestyle among its customers. With the concept of "caring cosmetics". The Body Shop has produced cosmetics as a specific brand value for customers. The firm uses its products to signal larger political values and ideals and to connect them with strong emotional content. In this sense, The Body Shop has turned its green profile into a religion (Rendtorff in Koslowski, 2010, p. 40).

We can mention many other examples of companies that have worked to foster immaterial values, who have increased the emotional significance of their brand and their products for customers, and that also have intensified employee motivation. As mentioned previously, it is the task of corporate religion to link the customers to the firm by emphasizing that the products of the firm are expressions of attitudes and values. In this context, corporations organize events and other initiatives (e.g., making slogans that contribute to the promotion of a lifestyle through the image of the firm) in order to ensure 
the loyalty and emotional binding of individuals to the firm (Rendtorff in Koslowski, 2010, p. 41).

This ideological and strategic concept of corporate religion as the basis for promoting the legitimacy of corporations in modern society is based on a number of simple values and statements, which are imbued through all, levels of the organization through its mission statement. This mission statement should function like a Bible for the corporation. In the fight to establish an emotional engagement among employees and customers in the firm, it is important to work with simple and strong formulations of values in order to give the vision and mission of the firm strategic power and weight. Moreover, it is important to emphasize that corporate religion, based on a powerful and charismatic style of leadership, is an important condition for realizing the values of the firm. As a strong leader, the manager and CEO must present him- or herself as an incarnation and symbol of the values and personality of the totality of the corporation (Rendtorff in Koslowski, 2010, p. 41).

In strong opposition to the idea of corporate religion we find the existentialist approach to management, which considers corporate religion as purely manipulative. This existentialist approach to business ethics has been proposed recently by a number of authors, including the provocative young consultant Kirstine Andersen, in her book Kierkegaard. These authors are trying to apply existentialist thinking to the relations of management and work life. An existentialist approach to management can, at the same time, be considered as continuing to search for a deeper meaning to business life. Existentialism in management refuses to reestablish a mystical new spirituality, but rather the aim is to make the existentialist search for individual meaning the basis for the social legitimacy of the firm (Rendtorff in Koslowski, 2010, p. 41).

From a critical view of capitalism we can, however, ask whether there is an existentialist philosophy of management. Critical authors would state that existentialism and management cannot be combined and that this approach is an indication of an ideological use of existentialism to justify management. They would say that there is no room for singular existence and search for meaning in the large contemporary economic organizations and social systems. It looks very difficult to reestablish the individual meaning of life within the modern organization of work and it seems impossible to unite the private search for existential and religious meaning with specific work requirements in large organizations. This existentialist approach can be seen as a response to a Protestant ethics based on the search for meaning in organizations with the recognition of the conditions of economic life in modernity (Rendtorff in Koslowski, 2010, p. 42). 
Inspiration for basing corporate legitimacy on the existentialist calling can be found in the work of Soren Kierkegaard. Kirstine Andersen argues that Kierkegaard contributes to understanding management and governance by providing a poetic language of the working life. In existentialist philosophy, the search for dialogue and communication implies confidence and engagement with other human beings. Existentialism takes seriously the original signification of being a director, namely to search for a direction in existential terms. The manager is somebody who points to the direction of life and the experiences of life in organizations are concrete and existential. Existentialism can help us to perceive this concrete life in organizations. In the existential sense. managers are confronted with something larger than themselves when they have to make important decisions. Managers are choosing themselves and the situation when they make large decisions. They would have to deal with their professional life from the point of view of their existential engagement. Because it is impossible to ignore personal life and existence in professional life, its legitimacy is dependent on a harmonious relation between the personal and private convictions of individuals. Moreover, existential management is about recognizing the importance of human dignity and respect for employees and other stakeholders as human beings with infinite value (Rendtorff in Koslowski, 2010, p. 42).

Applying existentialist philosophy to management we can resume the existentialist challenge of management: The task of the manager is to come to terms with the fact that his/her role is a condition of life that he cannot escape, which is also a fact for the other human beings who are subordinate. Given this condition of his existence, the manager cannot avoid being forced to become him- or herself with a certain character, set of values, and particular conceptions of life. Indeed, it is an existentialist requirement fact that the ethical challenge is greater than the individual. There is a requirement of the ideality of the infinite in the ethics of existentialism, which assumes that moral and ethical choice involves existential engagement for the individual. As such. the strategy of legitimacy in existentialism implies a return to the personal conscience and engagement of the individual behind the mask of professional life as the basis for real professional commitment and responsibility (Rendtorff in Koslowski, 2010, p. 43).

As a modern version of Protestant ethics, existentialism puts the value of personal responsibility for one's action in the center of corporate legitimacy. But at the same time, the kind of existentialism that is proposed is in danger of loosing its roots in the critical attitude towards corporate life and becoming a new philosophy of meaning in the corporation, which after all is based on New Age philosophy. This would be the end of existentialism which means that the approach can indeed be criticized. Can we really build 
professional life on personal values? Isn't it better to work with strict separation of spheres of values, of ethics, law, economics, and religion? In this sense an existentialist turn in business ethics is dangerous because it moves from formal rules of professional life towards individual emotions and conceptions that are outside the objectivity of professionalism. However, the counter argument is that you cannot separate personal responsibility from public functions and that government and management is a kind of decision making, which implies great personal responsibility, accountability, and integrity (Rendtorff in Koslowski, 2010, p. 43).

The question arises whether this reintroduction of the individual and his or her responsibility to the center of management in the existentialist approach inspired by Kierkegaard, does not hide some new forms of subjugation and domination that pose the danger of becoming a new kind of corporate religion. This may require analyzing these new kinds of management as forms of power. As Michel Foucault has shown, power is not always coercive. It has to be more subtle to remain strong. Governmental power can, in this sense, include responsibility and spirituality by manipulating the liberty of the employees. There is not, as such, a contradiction between power and liberty. On the contrary, power becomes more intense and efficient if it is not limited to individual initiative (i.e., the possibility to decide and to resist) but rather is based on individual freedom, action, and the search for meaning in life. The placement of the individual in the center of management in corporate religion and in the existentialist search for meaning can, therefore, still imply powerful discipline and coercion. Thus, modern technologies of management have understood that. it is important to insist on spiritualization and individualization of management. As the sociologist Richard Sennett-a close friend of Michel Foucault-has shown, the organization of work leaves organization hierarchical structure of traditional government in order to substitute this power with a more subtle, personalized, and polycentric form of management. Without opposing the importance of an existentialist criticism of the concept of corporate religion, these contemporary approaches are very powerful as expressions of the hidden discipline of management technologies (Rendtorff in Koslowski, 2010, p. 44).

Accordingly, we can emphasize three important dimensions: 1) A general theory of organization, which is built on systems theory and polycontextual understandings of the relation between firms and their environments. 2) Conceptualization of a concept of leadership as opposed to management, which implies a discussion of the role of the good leader and how the virtues of integrity, dignity, and judgment can be determinants for the right development of organizations. 3) Understanding how the strength 
and power of discipline are hidden in the management technologies of corporate religion and existentialism. The general conclusion is, therefore, that these elements of theories and conceptions of the philosophy of management can help contextualize the importance of the emergence of corporate citizenship, CSR, business ethics, and values-driven management in the Danish and Indonesia context.

\section{Moral Goodness in Education}

Kierkegaard stands as an opponent of Hegel and all who seek to find systematic scientific explanation of human existence and behaviour including in education of field. He stands see moral goodness as the most important thing in life and also in education. With regard to Hegel and the scientists, Kierkegaard is relenting an explanation of human existence impossible in human life. It is this uncertainty and risk which provide the material for human freedom. While there may not be any logical reason why men could not be both free and have comprehensive, proven knowledge (and not merely beliefs) Kierkegaard thinks that human nature is psychologically or spiritually so constructed that freedom and absolute knowledge or certainty are incompatible. Human beings require difficulty, uncertainty, conflict and the like in order to develop a moral and spiritual disposition (Curtis \& Mays, 1978, p. 1).

With regard to science Kierkegaard fears that the tendency towards objectivity through observation will delude man into thinking that he understands himself through understanding his physiology or anatomy. All such scientific methods become particularly dangerous and pernicious when they encroach upon the spiritual field. Plants, animals, and stars may be handled in that way, but to handle the spirit of man in such a fashion is blasphemy which only weakens moral and religious passion. Man is qualitatively different from plants and animals (Curtis \& Mays, 1978, p. 2).

Kierkegaard writes, "My task is a Socratic task, to revise the definition of what it is to be a Christian". Kierkegaard back on the study of nature and science in order to study man and ethical-religious aspects of life. These are the only subjects worthy of the regard of free agents. Like Socrates, Kierkegaard spurns public life in order to serve his fellow citizens as a gadfly, calling into question the cliches and popular dogmas of the day. One can find striking parallels of Socratic ignorance, irony, introspection and maieuticism in Kierkegaard's writings as well as in his wider public behaviour. The aspect of Socrates' thought that Kierkegaard has most ingeniously appropriated to his own uses is the doctrine of moral knowledge: Virtue is knowledge. Kierkegaard appropriated this doctrine, but in doing so he changed it radically. For Socrates morality is thoroughly intellectualized. It is made a 
science. The emotions and irrational part of the soul are eliminated. For Socrates, to know the good is tantamount to doing the good whenever the occasion calls for it. Weakness of will (akrasia), as is well-known, is a concept conspicuously absent in the Socratic dialogues. Wrong doing is simply involuntary, due to ignorance. "My own opinion is more or less this: no wise man believes that anyone willingly sins or willingly perpetuates any base or evil act; they know very well that every base or evil action is committed involuntarily" (Curtis \& Mays, 1978, p. 3).

Kierkegaard's doctrine of morality is related to Socrates' dictum conversely. For Kierkegaard "virtue is not knowledge" but rather "knowledge is virtue". That is, unless the knower approaches the subject matter of ethics (and religion) with a good will he will not understand the subject matter. Unless a person is already committed to the good, he will never significantly understand what morality is about. Unless one is already striving to live within the light he already has, he will not be given any further light. This relation of will to knowledge has wider implications than the above suggests. For Kierkegaard all knowledge involves volition. It does so in as much as in every act of knowing interpretation is necessary and every interpretation involves, at some level, decision. There is no such thing as purely neutral perception. All perception involves interpretation, seeing something 'as something' and from a particular perspective. According to Kierkegaard, we are responsible for the interpretations we place on our sensations. This is part of what being a free agent means (Curtis \& Mays, 1978, p. 3).

The Kierkegaard's theory of 'The Principle of Cognitive Particularity', has affinities with the Latin, 'Quidquid cognoscitur, per modum cognoscentis cognoscitur'. That is, whatever is known must be known in a way appropriate to the knower. Everything I know, I know by virtue of my situation, capacities, and choices. There is no such thing as knowing simpliciter. The Principle of Cognitive Particularity is only part of the truth. There is a second epistemological principle which I find implicit in Kierkegaard's ideas, a principle which constitutes the unformulated backdrop againts which his theory of subjectivity is to be understood. I call this Kierkegaard's Cognitive Principle is known must be known in a mode appropriate to the thing known. This principle recognizes that there are objective structures in reality which, if certain results are to obtain, must be adhered to. This principle is especially applicable to competence-knowledge (knowing-how, learning skills). If I would bring about the state of affairs of my riding a bicycle, I must obey certain laws of nature, correlating my innate capacities and personal peculiarities with a specific two-wheeled machine. Unless there is an attitude or mood of obedience present I shall not learn to ride a bicycle. 
There is no logical necessity in correlating a mode of approach with a skill. Nature could have been different. However, this is how things are. There is a certain orderliness in nature which requires recognition if any learning is to take place. Learning is not an arbitrary process. There are objective factors. It should be clear that the Cognitive Principle are not contradictory but complement one another (Curtis \& Mays, 1978, p. 4).

The next factor which we should note in approaching Kierkegaard's epistemology is that learning (or developed knowing) is progressive. In order to understand a complex subject, I must necessarily understand its simpler components. In order to be able to solve problems of calculus I must understand simpler arithmetic. In order to use words to write an essay in philosophy of education, I must know how to use words in ordinary language. This is true in spite of some appearances to the contrary. For Kierkegaard his doctrine of 'stages of existence' relies on this principle. Unless a person goes through an 'aesthetic stage' (where pleasure and selfinterest dominate), he cannot appreciate or understand an ethical way of life. Unless he has lived in an ethical stage, he cannot appreciate or understand religious existence. Unless he understands through participation what it means to be religious, he cannot understand what it means to be a Christian. Existence has a certain teleology. Unless a person works through the particular dilemmas and tasks which he finds at hand, he will never make progress to a further and more complex state of existing (Curtis \& Mays, 1978 , p. 4).

Next we must consider the specific difference in Kierkegaard's thought between 'subject' and 'object'. In every relationship of knowledge a subject knows an object. When the manner of presentation is emphasized in the knowing relationship we call the relation 'objective'. What is being focused upon is the fact itself. It is a fact regardless of how I feel about it. It is true that I may not understand it unless I approach it in a certain mood (Cognitive Principle), but here the focus is on what is known, not on how I know it. Kierkegaard readily grants that all science must be, in this sense, objective: logic, natural science, psychology, mathematics, economics and the like are to be treated objectively so far as possible. However, sometimes it is more appropriate to focus attention on the knower rather than the object known. Or rather what the object demands is that the knower consider his feelings, his subjective state in the knowledge relation (Curtis \& Mays, 1978, p. 4).

Let me try to illustrate this. If I want to know whether Germany invaded Holland in the Second World War or Holland Germany, I make a proper study of the records available. I assess the evidence impartially. My feelings on how I wish things had been — say I am a German youth who 
wants to be proud of my Fatherland - has nothing to do with the matter, except in so far as it motivates me to make the study in the first place and concentrate carefully on the nature of the evidence. I cannot interpret the evidence simply any way I wish to. To make the wish father to the facts is simply subjectivism — something Kierkegaard has often been accused of through misinterpretation. Any objective mode of inquiry is appropriate to objective knowledge. My feelings about how I wish things were make not the slightest difference to how they are. I must strive for impartiality and distinterestedness in my judgment (Curtis \& Mays, 1978, p. 5).

However, there is a large zone of life where my feelings do make I lie decisive difference and ought to make the decisive difference. This is the area of life which is most important to me personally: $i$ lie general area of ethical and religious knowledge. Here the way I feel about things makes all the difference. My intuitions, passions, and partiality are vital. This is not merely because I do not have the necessary facts with which to operate impartially - though this is part of the situation. It is rather that knowing here involves a passionate dialectic between the knower and the subject matter. Even if I had proofs for the objective reality of religious and cilileal propositions, I would dismiss them and even detest them I w, cruse they would tend to falsify the mode of subjectivity. Ethical and religious truths are not known 'objectively' but only subjectively (Curtis \& Mays, 1978, p. 5).

Kierkegaard calls ethical-religious problems 'existential' problems. He uses the term 'existence' here to distinguish a higher mode of being from 'life' or merely living. Unreflective, uncommitted p-ople have life but do not exist as self-conscious potentiated persons. Self-consciousness, that which transforms life into existence, arises through the choices, the commitments we make (Curtis \& Mays, 1978, p. 4-5).

One may object that there is a certain ambiguity here. Earlier we said that all perception qua interpretation involves choice. Hence, everyone makes commitments of one sort or another. This is true. The difference between the person who merely has life and the person who exists is like the difference between the hill and the mountain. It may be impossible to point to any exact line where the one ends and the other begins. Kierkegaard's concern is to articulate clearly defined types not because we ever find any instances of these types but because it may help us understand what our lives are really about (Curtis \& Mays, 1978, p. 6).

The choices we make involve our whole being. They are not simply an intellectual matter. Our reason, emotions, and imagination are all involved. A person wills as a whole unitary being. Hence, it is wrong to elevate reason above the other aspects of man in valuing man. The true springs of action are deep within man, bound up with the passions (emotions and intuitions). The 
elevation of reason where it does not belong usually produces merely a state of deceptive rationalization. 'In existence thought is by no means higher than imagination and feeling. In existence all the factors must be co-present (Curtis \& Mays, 1978, p. 6).

Because ethical-religious choices affect us fundamentally, they cannot help but involve the emotions. Passionless thinking about these matters is a contradiction of a sort. As Kierkegaard sees it:

All existential problems are passionate problems, for when existence is interpenetrated with reflection it generates passion. To think about existential problems in such a way as to leave out the passion, is tantamount to not thinking about them at all, since it is to forget the point, which is that the thinker is himself an existing individual (Lowry, 1941. P. 64).

Let me try to illustrate what Kierkegaard is getting at in the distinction between objective and subjective knowledge. Consider the proposition, 'All men are mortal'. We all acknowledge the truth of this assertion whether we like it or not. It is a fact, objectively true. It is so incontrovertible that although it is not provable, it can be safely used as a major premise in the classical example of a deductive argument. Although I have heard this sentence uttered hundreds of time, I have never heard anymore manifest much emotion about it (Curtis \& Mays, 1978, p. 6).

Now consider the statement. 'You are going to die within a few days' (or alternatively, 'Your loved one is going to die within a few days') uttered by an authority (e.g. your doctor or a kidnapper). If you consider this assertion, no doubt it will arouse in you a great deal more emotion than the general proposition about $\mathrm{t}$ fie general mortality of mankind. You are forced to think with some feeling about what the implications of your death will be. What will your wife do? What will your children do without you? How will your work be judged? If you do not raise questions like I hese, if you do not feel intense emotion at the threat to your (your loved one's) being, I think we would be justified in concluding I here is something inhuman about you. Such is the remarkable case of Camas' Stranger. It may be possible to produce individuals who are like the Stranger, disinterested about their own and other's spiritual welfare, regarding themselves as objects, but it is not a good thing. There are some things about which it is positively inhuman to be objective. Unless I respond with appropriate emotion i o certain facts, I cannot be said to have understood what is involved in those facts (Curtis \& Mays, 1978, p. 7).

The next step in our analysis of Kierkegaard's theory of subjectivity is to distinguish its epistemological aspect from its ethical aspect. We have already noted in our discussion of the Cognitive Principle and the subjective- 
objective distinction some features of I lie epistemological aspect, especially that there is a class of relationships between the person (subject) and the cognitive object in which the relationship, if it is to be a satisfactory one, must be subjective. Here the emphasis is strongly on the mode of approach. Indeed, Kierkegaard uses the adjective 'true' to characterize the relationship regardless of the objective truth value of what is believed.

When the question of truth is raised in an objective manner, reflection is directed objectively to the truth, as an object to which the knower is related. Reflection is not focused upon the relationship, however, but upon the question of whether it is the I rush to which the knower is related. If only the object to which he is related is the truth, the subject is accounted to be in the truth. When the question of truth is raised subjectively, reflection is directed subjectivity to the nature of the individual's relationship; if only the mode of this relationship in the truth, the individual is in the truth, even if he should happen to be thus related to what is not true (Lowry, 1941, p. 64).

Kierkegaard illustrates what he means by the parable of the two worshippers.

If one who lives in the midst of Christendom goes up to the house of God, the house of the true God, with the true conception of God in his knowledge, and prays in a false spirit; and one who lives in an idolatrous community prays with the entire passion of the infinite, although his eyes rest upon the image of an idol: where is there most truth? The one prays in truth to God though he worships an idol; the other prays falsely to the true God, and hence worships in fact an idol (Lowry, 1940, p. 36).

In existential matters, the mode of approach is decisive. Only the person who has the right attitude is in truth. The corollary of this thesis is that the proper 'how' leads inexorably to the right 'what'. That is, the properly subjective person will, letting his conscience be his guide, arrive nearer and nearer to a correct objective understanding. As Kierkegaard writes in his journals:

In all that is usually said about Johannes Climacus being purely subjective and so on, people have forgotten, in addition to everything else concrete about him, that in one of the last sections he shows that the curious thing is: that there is a 'how' which has this quality, that if it is truly given, then the 'what' is also given; and that it is the 'how' of 'faith'. Here, quite certainly, we have inwardness at its maximum proving to be objectivity once again. And this is an aspect of the principle of subjectivity, which, so far as I know, has never before been presented or worked out (Journals 45).

We turn now from the form of subjectivity, the epistemological aspect, to the content of subjectivity: the ethical aspect (i.e. ethical in a broad sense, as including all existential concerns). Climacus makes a distinction between essential knowledge and accidental knowledge. Essential knowledge relates to one's personal existence. Accidental knowledge is related to the intellect 
alone. It has no fundamental significance for my life. 'Only ethical and ethicoreligious knowledge has an essential relationship to the existence of the knower.' The essential-accidental distinction seems to be based on Kierkegaard's anthropology. Man is essentially dual. On the one hand, he is body-soul, a highly developed animal. On the other hand, he is spirit, that is a free agent capable of making ethical and religious decisions, capable of selfknowledge. In being spirit he is higher than the animal world. Implicit in this priority of I lie spiritual over the animal is an ordering of values. Whatever is more distinctly spiritual is of a higher value than what is less distinctly spiritual (Curtis \& Mays, 1978, p. 8-9).

Sometimes Kierkegaard calls these dual properties of man infinityfinitude', 'eternal-temporal', 'freedom-necessity'. The goal of life is to become as spiritual as possible, to die to the flesh in order to live in the spirit. Only the spiritual man is the free man. He is free from the bondage of guilt, free for service to God and man. At he top of the value-hierarchy is the religious existence, spirituality at its pinnacle, but the ethical is the necessary condition for the religious and is incorporated within it (Curtis \& Mays, 1978, p. 9).

Realizing one's ethical-religious task is a lifetime affair. One is never done with it. Hence there is no time to become complacent about results, but rather the individual must constantly be looking forward towards an ideal self. Climacus sums up the ethical religious task in saying that the individual ought to commit himself hsolutely to the absolute and relatively to everything relative. That which is essential to his highest development is his God-relationship. Everything else is of secondary importance (Curtis \& Mays, 1978, p. 9).

Before leaving our analysis of subjectivity we must examine a final claim made by Kierkegaard, the claim that 'subjectivity' is truth. We have already noted that Kierkegaard has often been accused of subjectivism. The charge is founded on a misunderstanding of this epigram. Kierkegaard himself is not altogether free from blame, for there are passages which lend themselves to such an interpretation. I can only hope that my analysis has shown this to be a rather crude and poor interpretation of a more complex iheory. It is not at all the case that my subjectivity determines objective truth, but it is simply that subjectivity is the only way to approach the truth or to understand the truth. Concerning existensial concerns passionate concern is the only appropriate expression. Just as objective truth is expressed as a correspondence between, wence and state of affairs, so subjective truth is a correspondence between the individual's inner disposition and the ideal he insiders to be true. Subjective truth is the mutual fit of the personality with the object of belief. Whereas the image that comes to mind in objective truth 
is a photograph of a state of affairs, the image expressing subjective truth is one of a work of art. The individual with his eyes on the ideal, uses umagination, reflection, the emotions, and above all, the will in order to create a personal existence approximating the ideal. "The only fundamental basis for understanding is that one himself becomes what he understands and one understands only in proportion to becoming himself that which he understands. In calling 'subjectivity' the truth Kierkegaard is, of course, using a secondary meaning of 'true', true as 'conformable to a standard'. Ultimately, for Kierkegaard 'subjectivity' alone is 'untruth'. It must have objective truth as its correlate or it must give up the predicate 'truth' (Journals....396, 488).

I turn now to the application of Kierkegaard's theory to education. Just as I have divided the theory of subjectivity into two separate aspects: the epistemological and the ethical; so I shall briefly discuss Kierkegaard's contribution to philosophy of education under those two headings. Regarding the ethical aspect, we see that according to his theory all knowing has an ethical dimension. We are responsible for what we learn in that we have the obligation to use it for the furtherance of moral ends. Furthermore, the knowledge which is most to be sought is ethical knowledge. The primary aim of all the institutions of society should be to produce morally sensitive persons - even if success can never be guaranteed (given the assumption of human freedom). It is better to have good people than clever or materially successful people. It is better to be a good person, one absolutely committed to the ethical-religious dimension of life, than to be cultured or distinguished or successful. It follows from this premise that there can be no such thing as neutral teaching regarding moral values. Either you are committed to handing down the tradition of ethical truths to children from the earliest ages upwards or you have failed to see the significance of moral truth (Curtis \& Mays, 1978, p. 10).

Knowing how to make ethical decisions, knowing how to treat other people, are of far more importance than knowing anything else. Kierkegaard certainly sounds out of step with current educational policy when he writes:

The main objection ... to natural science may simply ... be expressed thus, it is incredible that a man who has thought infinitely about himself as a spirit could think of choosing natural science ... as his life's work and aim (Swenson \& Lowrie, 1941. P. 176).

No doubt this is an exaggeration. There is no good reason why science and morality cannot cooperate, why a man with spiritual insight cannot also be a person of moral and spiritual force. The question is one of priorities not of exclusions. Kierkegaard's contribution is not that he rightly understood the role of science but I hat he got his priorities right. He saw with 
remarkable clarity that the moral existential dimension of life is what is of first importance (Curtis \& Mays, 1978, p. 10-11).

Regarding the epistemological aspect of subjectivity and its relationship to learning, the following must suffice. Only what is learned through experience, personally appropriated, is truly $\mathrm{k}$ nown. In this sense life is education. It is 'the curriculum one has to run through in order to catch up with oneself, and he who will not pass through this curriculum is helped very little by the fact that lie was born in the most enlightened age (Swenson \& Hong, 1962. P. 38).

Formal education should be an art, wherein the teacher aids the pupil to discover knowledge for himself, arousing his interest.

What is really important in education is not that the child learns this or that, but that the mind is matured. That energy is aroused.... One can make oneself [a good head] if one will. Give a man energy, passion, and with that he is everything (Swenson \& Lowrie, 1942, p. 177).

This view of formal education may be contrasted with what Kierkegaard regards as a systematic, scientific process of education in which children are treated as products. 'If children could be shut up in the dark and force fed on an accelerated schedule like chickens, everything would certainly be organized to this end (Swenson \& Lowrie, 1942, p.176).

Finally, the teacher has an imcomparable role to play in the education process. The teacher does not merely teach a subject. In teaching a subject he or she teaches a way of life, whether the lc,icher realizes this or not. The teacher conveys values every Moment he is in the presence of the pupil. He 'gesticulates with the whole of his existence (Lowrie, 1941, p. 45).

For Kierkegaard, as for his teacher Socrates, all learning comes down to self-learning, even if it has originated in a dialogue. The person is responsible for what he learns and how he uses it. Only that which really is appropriated and made his own is his truth (Curtis \& Mays, 1978, p. 11).

One may have known a thing many times and attempted it; and yet it is only by the deep inward movements, only by the indescrihable emotions of the heart, that for the first time you are convinced that what you have known belongs to you, that no power can take it from yiu; for only the truth which edifies in truth for you (Swenso \& Lorie, 1942, p. 311).

\section{Rationality of Islamic Education Management}

Now, one way to go about reflecting about rationality and both "education" and "education management" is simply to claim that we already know_what true scientific rationality is all about- and both "education" and "management" must "conform" to this model in order to be a truly rational or truly scientific practice itself. And this view in some ways goes back to 
Plato/Aristotle - who determined that the way out of the resultant relativism and scepticism of pre-Socratic science was not to determine the right content or " object of science - but rather the right" form" or "method" of science. So a very dominant way of thinking about science in general in Western thought has been that the key to success is to know "theoretically" what science is, and then to judge any particular practice, such as "education", that claims to be scientific, against that particular theory. And at least from the enlightenment onwards (but really - already present in Plato and Aristotle), failure of an activity to meet a standard of science has meant that said activity was considered second rate at best and pernicious at worst (hence a denigration, for example, of the arts and religion). Of course, this general approach to defining scientific practice does not in the least solve all the problems - because even granting this model: what then ensues is a few thousand years of debate about precisely what that "method" or "form" of science is to be. Just to mention a few recent examples: we have "positivist" agenda of amassing facts thought inductive principles in order to "verify" a theory, or the idea that science progresses through an unending cycle of perhaps unjustified conjectures which one attempts to test and potentially "falsity" - a theory of scientific praxis associated with Karl Popper. But what interest me is that whether on is a "positivist" or a "popperian" - these apparently different ways of thinking about science actually share some very basic premises (Buckley, 2014).

First,_they share the notion that "theory" is something distinct from "practice (praxis)" and that theory "prescribes" or dictates practice: second, share presuppositions about "objective" reality being something one can have pure "facts" about - basically an assumption about "nature" as some sort of self-subsistent reality; and third, that methods is itself something nonquestionable once established. Put strongly, the principle of falsification, for example, is itself not open to falsification. These are highly questionable presuppositions, rooted in a long tradition of thinking about science that can be challenged, and is often challenged today (Buckley, 2014).

\section{Narrative Model}

Because these challenges go deep enough - they call into question entire ways of thinking about science: in short, is it, in fact, the case that we have a crystal-clear theoretical sense of what science is and that is simply a matter of this clear sense dictating practice? The answer in many quarters is "no", and those who propose such a negative answer often are looking for other ways to describe "science"-and in doing so they often turn the ancient theory/practice dichotomy on its head: saying lets look at "practices" and see what they tell us about "rationality". They want to show that practice 
is not always driven, or best understood by some preordained theory, but is guided by different models of knowing. What sort of models do these antitheorists propose? One of note might well be called the "narrative" or "discursive" model (Buckley, 2014).

I attended an Osler lecture a number of years age at McGill (I can't remember the speaker but I do more or less recall the content) wherein the essence seemed to be that when one describes medical learning - it (medical learning) is seen to possess a narrative structure. Not surprisingly then, she placed a great deal of emphasis on the role of case histories. Her argument was then strongly opposed to the rational-theory model: medical students learn most (or perhaps, she was implying, they learn "best"?) not by apprehending some theory of scientific practice and applying to medicine; rather they learn "most" or "best" by injecting themselves into a vast textual network of case histories. Learning medicine on this account is somewhat akin to a child learning to read: children surely do not apprehend some complicated semiotic theory and then read! Rather, they learn by being read to, by imitating their parents, by internalizing the stories themselves and then mapping then on to the squiggles on the page. Once having mastered this skill, they can then go on to enrich their textual network - and a truly skillful reader is one who has entered into a complex wed of stories - such that a reference to Dante in Joyce's Portrait of an Artist as a Young Man is grasped (either implicitly or explicitly) and the next is alive with meaning. There are many intriguing aspects to this notion, and it does seem to bear thinking about in terms of social work education and practice (Buckley, 2014).

If I recall correctly, I thought at the time and probably still do think that this speaker may have pushed the "narrative" model a little too far; in a way swinging to the opposite pole from our first rational-theory model science/medicine is basically what we say it is. In doing so, she did not provide any genuine account of the basic structure of narrative - what makes something identifiable as a story, nor any principle of discrimination about what makes one story better than another. And so while I deeply appreciated her motives to provide a more descriptive rather than prescriptive account of medical learning and practice - I think more must be thought out before I accept wholeheartedly the "narrative" model (Buckley, 2014).

\section{Political Model}

A third model I can be envisioned - and here I am relying on sociologists of science such as Bruno Latour: might be called the "political" model. Here we enter a middle ground between a scientific ideology that dictates praxis and a descriptive approach that ends up not able to give a thorough account of the conditions of possibility for there being such a thing 
as a narrative. The result is that Bruno Latour gives a far more sophisticated - and complex account of scientific rationality. A few highlights: first, contra model \#1, he is very critical of the idea of "nature" as some sort of external, unifying entity that could always be turned to as home base. Put another way, he assaults the classic fact/value distinction as a certain type of "two chamber" system - where discussion takes place in the realm of values but the arbitration of that discussion takes place in the realm of nature. $\mathrm{He}$ introduces in his typology of science an extremely complicated "fourchamber" model wherein within each chamber facts and values were recognized as co-existing - but in differing hierarchical relationship. What "nature" "is" (and I think the corollary to what "nature" is for science in general could probably be3 called "knowledge for educators") - what this "nature" or "welfare" "is" - is no longer something outside the practice of science that seeks to know it or of the practices which seek to promote it but nature/knowledge is itself the product of political discussion (and here he might be said to be ending towards the narrative side); nevertheless the political discussion has strict constitutional requirements which generate its stability and informs it with principles of distinction. Hence, to say that "all" science (and hence, "all" social work too) is politics is not to make science or education or management into some sort of free for all, nor to divest it of its concern for "nature" or "welfare", but it is to recognize that the "concern" itself is part the process of establishing "nature" and to set fort rules of legitimization (legislation) which guide the process, lend it some stability, but do not petrify the system (laws change, after all) (Buckley, 2014).

\section{Athletic Model}

Running in Jakarta earlier this week; I cannot resist proposing a further model: which I name the "athletic" model. This model incorporates some aspects of the previous models. On this account, being a good scientist or a good teacher/educator or a good manager is somewhat akin to being a good athlete. Athletes like our young child learning to read, surely do not learn nor master their sport through theory. No amount of theory is going to make me into an NBA player - though even I might be able to help the Toronto Raptors at this point. There are politically determined rules of the game, but these rules are conditions having the rules does not in itself produce "generate" a good hockey. And as we know, these rules are not immutable; though, it must be said, they also cannot be tinkered with lightly. One advantage of athletics, and the formation and practice of good athletes as a model for thinking about education and management is that it adds a more explicit bodily dimension to the previous models. Being a skillful athlete means possessing a type of knowledge - but surely not of a theoretical type 
(!) [It would indeed, it seems to me, disqualify most professional athletes were we to demand such theoretical knowledge]. The knowledge is probably best named "body-knowledge", and it is a combination of natural ability, physique, training, aptitude, personality, and so forth. It seems to me not inappropriate to think of the skillful educator or the caring manager as having acquired just such a bodily knowledge, expressed in good decisions under pressure, the right word or touch at the right time (Buckley, 2014).

\section{Towards an "artistic" and an "ethical" model}

What I am doing here is not really trying to champion one model (though I clearly have my favorite), but simply to get our minds thinking about the different ways one imagine scientific rationality in general and social practices such as education and management in particular. But of course, as one runs through these models, a strange conclusion emerges. Since our view of scientific rationality has for so long been enframed by model number one - that is, we almost cannot imagine "science" when it comes to describing activities, such as social work perhaps, that more closely correspond to our other models. What other name could we call these activities? Well, two rather old names come to mind. The first is "arts". Here we may simply be invoking yet another model - an aesthetic model - that in some way incorporates successfully as well many of the elements of the models we have discussed: a successful artist too seems to be skilled in a bodily way in a manner akin to an athlete; with perhaps one additional advantage made more explicit. Namely, the work of art lives on after the artist disappears from the scene; producing effects not imagined and bringing pleasure to unknown admirers. This seems particularly appropriate to the labour of education, where the benefits and effects of success live on in countless ways and touch lives unknown to you at the moment (Buckley, 2014).

Which brings us to another model, also very old. And I suppose we would have to call this the "ethical" model. For Aristotle, the virtues were divided into two groups: the moral virtues and intellectual virtues. And while he gave preference to the intellectual virtues (and hence, he does in some ways lay at the base of model \#1); it may be appropriate to look the moral virtues as interesting models for the "virtue" of practicing social work. To be morally virtuous for Aristotle is to act in a manner appropriate to the situation. This is why a virtue such as "courage" can shift from event to event. For Aristotle, it is not courageous to run alone into an army of spearwaving charging Spartans - it is, rather, not only stupid but displays the vice of recklessness however it is also a vice, "cowardice", to run away from a mouse. Being courageous is to learn by practice, by listening to your elders, 
by hearing the ancient stories and emulating the heroes of old, to do the right thing in the right situation. This learning is not the mastery of a theory, but is rather a learned practice that he calls - interestingly - a "habit". It is an intuitive, bodily, habituated sense of what is right, of what is just. Virtue may not always lead to success, but it places one in a position to assess one's past failures and to aim for improvement in the future (Buckley, 2014).

It occurs to me that by ending with this vague suggestion that social work skill may be acquired and practiced in a manner rather analogous to Aristotle's treatment of the acquisition of "virtue", my talk has, led to a new problem - what is the relation between ethics and religion. How is that religion might "properly" inscribe an "ethical" attitude? An excellent philosophical question - but one for another day!(Buckley, 2014).

\section{Phenomenological Approaches in Islamic Education Management Research}

The approachs of phenomenological research as well as the development of theory, concepts, and proccesses involved in human science inquiry come from the Duquesne Studies in Phenomenological Psychology (Giori et al. 1971-1983). The approach involves a return to experience in order to obtain comprehensive descriptions that provide the basis for a reflective structural analysis that portrays the essences of the experience. The approach "seeks to disclose and elucidate the phenomena of behaviour as they manifest themselves in their perceived immediacy" (van Kaam, 1966. P. 15). The human scientist determines the underlying structures of an experience by interpreting the originally given descriptions of the situation in wich the experience occurs. The researcher can let the phenomena speak for themselves (Moustakas, 1994: 11-13).

The steps involved in empirical phenomenological studies as outlined by von Eckartesberg (1986) follow: 1) the problem and question formulation-the phenomenon. The researcher delinecates $s$ focus of investigation....formulates a question in such a way that it is understandable to others; 2) the data generating situation-the protocol life text. Researchers start with descriptive narrative provided by subjects who are viewed as co-researchers...we query the person and engage in dialogue, or we combine the two; 3) the data analysis-explication and interprtation. Once collected, the data are read and scrutinized so as to reveal their occurrence and clustering ...emphasis is on the study of configurations of meaning....involving both the structure of meaning and how it is created (von Eckartsberg, 1986.p. 27). 
In deriving evidence in phenomenological investigations, the scientific researcher establishes and carries out a series of methods and procedures that satisfy the requirements of an organized, disciplined and systematic study. These include: 1) discovering a topic and question rooted in autobiographical meanings and values. as well as involving social meanings and significance; 2) conducting a comprehensive review of the professional and research literature; 3) constructing a set of criteria to locate appropriate co-researchers; 4) providing co-researchers with instructions on the nature and purpose of the investigation, and developing an agreement that includes obtaining informed consent, insuring confidentiality and delineating the responsibility action of the primary researcher and research participant, consistent with ethical principles of research; 5) conducting and recording a lengthy personto-person interview that focuscs on a bracketed topic and question. A followup interview may also be needed; 6) organizing and analyzing the data to facilitate development of individual textural and structural descriptions, a composite textural description, a composite structural description, and a synthesis of textural and structural meanings and essences (Moustakas, 1994, p. 103-104).

The above methodological requirements may be organized in terms of methods of preparation. Methods of collecting data, and methods of organizing and analyzing data. A method offers a systematic way of accomplishing something orderly and disciplined, with care and rigor. Procedures or techniques make up a method, provide a direction and steps to be followed, and move a study into action. Every method in human science research is open ended. There are no definitive or exclusive requirement. Each research project holds its own integrity and establishes its own methods and procedures to facilitate the flow of the investivatior and the collection of data (Moustakas, 1994, p. 104).

\section{Formulating the Question}

The first challenge of the MPI researcher, in preparing to conduct a phenomenological investigation, is to arrive at a topic and question that have both social meaning and personal significance. The question must be stated in clear and concrete terms. The key words of the question should be defined, discussed, and clarified so that the intent and purpose of the investigation are evident. The position of each key word, or focus, of the question determines what is primary in pursuing the topic and what data will be collected (Moustakas, 1994, p. 104).

In phenomenological research, the question grows out of an intense tangents of it may complicate an articulation of a manageable and specific question. Yet this process of permitting aspects of the topic to enter into 
awareness is essential in the formulation of a core question that will remain viable and alive throughout the investigation. A human science research question has definite characteristics: 1) It seeks to reveal more fully the essences and meanings of human cxperiCnce; 2) It seeks to uncover the qualitative rather than the quantitative factors in behavior and experience; 3) It engages the total self of the research participant, and sustains personal and passionate involvement; 4) It does not seek to predict or to determine causal relationships; 5) It is illuminated through careful, comprehensive descriptions, vivid and accurate renderings of the experience. rather than measurements, ratings, or scores (Moustakas, 1994: 104-105).

\section{Validation Of Data}

A good example of validation of data is borrowed from Humphrey's (1991) study of "searching for life's meaning." Humphrey interviewed 14 coresearchers in exploring his topic description of their experience. He requested of each participant that she or he carefully examine the unified description of the search for life's meaning and that additions and corrections be made. Of the 13 who responded, 8 stated that the synthesis was accurate and that no changes were needed.

Humphrey comments:

The fourteenth was contacted twice by mail and twice by phone, but did not respond. Three offered important suggestions concerning omissions or questions of emphasis. Two indicated that they did not believe that the "dark side" of their search for meaning-the terrifying sense of meaningless or universal chaos which they sometimes experienced-was adequately represented.... This was an eye-opening confrontation to me, inviting me to look more closely at my own fear of the existential void and hidden desperation which might lead one to hold onto something rather than risking the apparent abyss of meaninglessness. I had thought that my heuristic exploration of my own scared had been thorough.... I had been aware that two transcribers had resigned from continuing to work on my project while they were working on two different research interviews right at the point at which the participants were describing comprehensively their fear meaninglessness. Cleary this is a powerful and difficult aspect of the search for meaning which some of us would rather avoid. Fortunately, the step of participant validation highlighted the reduced emphasis on this aspect. I returned to ... my own search and also reexamined the research interviews. (pp. 81.82) (Reprinted by permission of the author) (Moustakas, 1994, p. 111).

Humphrey revised the "synthesis" statement, significantly expanding the qualities and meanings of the dark side of searching for life's meaning.

\section{Review of The Professional and Research Literature}

Another method of preparing to conduct a phenomenological study involved review of the professional and research literature connected with 
the research topic and question. The investigator assesses the prior relevant studies; distinguishes their designs, methodologies, and findings from the investigator's own study; and indicates what new knowledge he or she is seeking and expects to obtain (Moustakas, 1994, p. 111).

Cooper (1989) has identified four major kinds of literature review. The integrative review presents the "state of knowledge" relevant to a topic and draws conclusions from the many separate studies that arc reviewed. These studies typically define the problem, outline the methods of data collection, evaluate the data, make analyses and interpretations, and present the findings. The theoretical review analyzes the theories that account for the existence of the phenomenon. The methodological review examines the rcscarch methods developed and utilized in the published works. The thematic review organizes the core themes presented in the studies and presents their findings within the core themes. Regardless of the approach, both formal and informal methods are used (Moustakas, 1994, p. 112).

Manual and of informal sources might include a follow-up of references cited in review papers on the topic as well as those appearing on book lists obtained from library indexes; browsing in bookstores and libraries, contacts with experts on the topic, conversations with professors and other students; documents of relevant government agencies; studies of comments on the topic from past reviews of the litcraturc; and attendance at professional meetings. In determining the key descriptors for locating rcfcicnccs, the Thesaurus of Psychological Index Terms and comprehensive dictionaries are utilized (Moustakas, 1994, p. 112).

From his survey of 57 authors of research reviews covering psychology and education, Cooper (1989) determined that the significance of the references were derived from various searches. The most central were: computer searches of abstract databases, such as ERIC and Psych-INFO; manual searches of abstract databases; computer searches of a , citation index, such as SSCI; manual searches of a citation index; references in review papers written by others; and references in books Cooper (1989) summarizes the purposes for using the technical and nontechnical literature. The technical literature includes: theoretical sensitivity regarding concepts and relationships in order to look for evidence from one's own research that confirms or rejects the relevancy of the concepts and relationships and in order to learn ways of approaching and interpreting one's data; secondary sources of data may provide useful interviews and field notes as well as descriptive materials of relevant events, actions, and perspectives of the research participant; guides to questions to explore with one's co-researchers, ideas helpful in developing one's theory, and supplementary validation of the accuracy of one's research findings (pp. 51-52). The nontechnical 
literature "can be used as primary data, especially historical and biographical studies. In most studies they (i.e., letters, biographies, diaries, reports, videotapes, and newspapers) are important sources of data, supplementing the most usual interviews and observations" (Cooper. 1989. p. 55 in Moustakas, 1994, p. 112-113).

\section{Methods of Data Collection}

Typically in the phenomenological investigation the long interview is the method through which data is collected on the topic and question. The phenomenological interview involves an informal, interactive process and utilizes open-ended comments and questions. Although the primary researcher may in advance develop a series of questions aimed at evoking a comprehensive account of the person's experience of the phenomenon, these are varied, altered, or not used at all when the co-researcher shares the full story of his or her experience of the bracketed question (Moustakas, 1994, p. 114).

Often the phenomenological interview begins with a social conversation or a brief meditative activity aimed at creating a relax; $\mathrm{d}$ and trusting atmosphere. Following this opening, the investigator suggests that the co-researcher take a-few moments to focus on the experience, moments of particular awareness and impact, and then to describe the experience fully. The interviewer is responsible for creating a climate in which the research participant will feel comfortable and will respond honestly and comprehensively (Moustakas, 1994, p. 114).

\section{General Interview Guide}

Sometimes a general interview guide, or topical guide, is used when the co-researcher's story has not tapped into the experience qualitatively and with sufficient meaning and depth. Broad questions, such as the following, may also facilitate the obtaining of rich, vital, substantive descriptions of the coresearcher's experience of the phenomenon. The language and timely way in which the questions are posed facilitates full disclosures of the coresearcher's experience. 1) What dimensions, incidents and people intimately connected with the experience stand out for you? 2) How did the experience affect you? What changes do you associate with the experience? 3) How did the experience affect significant others in your life? 4) What feelings were generated by the experience? 5) What thoughts stood out for you? 6) What bodily changes or states were you aware of at the time? 7) Have you shared all that is significant with reference to the cxperitnce? (Moustakas, 1994, p. 116). 


\section{Organization And Analysis Of Data}

Organization of data begins when the primary researcher places the transcribed interviews before him or her and studies the material through, the methods and procedures of phenomenal analysis. The procedures include horizonalizing the data and regarding every horizon or statement relevant to the topic and question as having equal value. From the textures and structures into the meanings and essences of the phenomenon are constructed (Moustakas, 1994, p. 118).

\section{Modification Of The Van Kaam Method Of Analysis Of Phenomenological Data}

Using the complete transcription of each research participant; 1) Listing and Preliminary grouping. List every expression relevant to the experience- (Horizonalization); 2) Reduction and Elimination: To determine the Invariant Constituents: Test each expression for two requirements; (a) Does it contain a moment of the experience that is a necessary and sufficient constituent for understanding it? (b) Is it possible to abstract and label it? If so, it is a horizon of the experience. Expressions not meeting (tie above requirements are eliminated. Overlapping, repetitive, and vague expressions are also eliminated or presented in more exact descriptive terms. The horizons-that remainare the invariant constituents of the experience; 3) Clustering and Thematizing the Invariant Constituents: Cluster (he invariant constituents of the experience that are related into a thematic label. The clustered and labeled constituents arc the core themes of the experience; 4) Final Identification of the Invariant Constituents and Themes by Application: Validation. Check the invariant constituents and their accompanying theme against the complete record of the research participant. (1) Are they expressed explicitly in the complete transcription? (2) Are they compatible if not explicitly expressed? (3) If they arc not explicit or compatible. they are not relevant to the co-researcher's experience and should be deleted; 5) Using the relevant, validated invariant constituents and themes, construct for each co-researcher an Individual Textural Description of the experience. Include verbatim examples from the transcribed interview; 6) Construct for each co-rcscarclier an Individual Structural Description of the experience based on the Individual Textural Description and Imaginative Variation; 7) Construct for each research participant a Textural-Structural Description of the meanings and essences of the experience. incorporating the invariant constituents and themes (Moustakas, 1994, p. 120-121). By the explantion, there are statement that from the individual temural-structural descriptions, develop a composite description of the meanings any' essences of the experience, -representing the group as a whole. 


\section{Modification of The Stevick -Cola Izæi- Keen Method of Analysis of Phenomenological Data}

A second method of organizing and analyzing phenomenological data is derived from any modification of methods of analysis suggested by Stevie!: (1971), Coiaizzi (1973), and Keen (1975). Each of the steps is presented in the appropriate order of analysis; 1) Using a phenomenological approach, obtain a full description of your own experience of (he phenomenon); 2) From the verbatim transcript of your experience complete the following steps: (a). Consider each statement with respect to significance for description of the experience; (b). Record all relevant statements; (c). List each nonrepetitive, nonoverlapping statement. These are the invariant horizons or meaning units of the experience; (d). Relate and cluster the invariant meaning units into themes; (c). Synthesize the invariant meaning units and themes into a description of the textures of the experience. Include verbatim examples; (f). Reflect on your own textural description. Through imaginative variation, construct a description of the structures of your experience; (g). Construct a textural-structural description of the meanings and essences of your experience; 3) From the verbatim transcript of the experience of each of the other co-researcher, complete the above steps, a through; 4) From the individual textural-structural descriptions of all coresearchers' experiences, construct a composite textural-structural description of the meanings and essences of the experictice, integrating- all individual textural structural descriptions into a universal description of the experience rcprcscnting the group as a whole (Moustakas, 1994: 122).

In the sections that follow, from various research investigations, I will offer examples of horizonalization; delimiting to invariant horizons or meaning units, clustering the invariant constitucpts into themes. Individual textural and individual structural descriptions, composite textural and composite structural descriptions, and synthesis of textural and structural meanings and essences.

\section{CONCLUSION}

In order to become a well-established science, Islamic Education Management should not be overly dominated by theology. Therefore, Islamic Education Management can build the scientific foundation of phenomenology, apart from the scientific method positivistic. Phenomenology can be an alternative formulation of science MPI because: 1) is natural (no reduction on pre-thought); 2) can reach the essence of the phenomenon; 3) systematic and 4) suitable for digging symptoms theological, historical, sociological and psychological principals and education managers Islam. There are four models of epistemology phenomenology that can be 
used as a basis in developing science education management, namely; (1) Narative; (2) Political; (3) Atletic dan 4) Artistic dan Etical model. Stages of research-based education management can take the phenomenology of qualitative research phases. There are some differences between ordinary qualitative research with phenomenological qualitative research, namely 1) return to experience in order to obtain comprehensive descriptions that provide the basis for a reflective structural analysis that portrays the essences of the experience; 2) seeks to disclose and elucidate the phenomena of behaviour as they manifest themselves in their perceived immediacy; 3) scientist determines the underlying structures of an experience by interpreting the originally given descriptions of the situation in wich the experience occurs. The researcher can let the phenomena speak for themselves. The steps involved in empirical phenomenological studies as outlined by follow: 1) the problem and question formulation-the phenomenon. The researcher delinecates as focus of investigation....formulates a question in such a way that it is understandable to others; 2) the data generating situation-the protocol life text. Researchers start with descriptive narrative provided by subjects who are viewed as coresearchers...we query the person and engage in dialogue, or we combine the two; 3) the data analysis-explication and interprtation.

\section{BIBLIOGRAPHY}

Moustakas, Clark., (1994). Phenomenological Research Methodes, California, London, New Delhi: Sage Publications.

Creswell, J. W., (2009). Research Design Qualitative, Quantitative, and Mixed Methods Approaches. Los Angeles: Sage Publications.

Curtis, Bernard \& Mays, Wolfe. (1978). Phenomenology and Education SelfConsciousness and Its Development. London: Methuen.

Dru, A., (1938). The Journal of Soren Kierkegaard. Oxford/New York, entries $806,1278$.

Swenson, D, F. \& Hong, H., (trans)., (1962). Philosopical Fragments or a Fragment of Philosophy, (New York: Princeton).

Koslowski, Peter., (2010). Elements of a Philosophy of Management and Organization Springer: Verlag Berlin Heideberg.

Lowrie, W (trans)., (1941). The Sickness unto Death. A Cristian Psychological Exposition for Edification and Awakening, London: Princeton. 